\title{
Russian Military Capability in a Ten-Year Perspective - 2019
}

Fredrik Westerlund \& Susanne Oxenstierna (red.)

Stockholm: FOI, 2019

146 sider. ISSN 1650-1942

Omtalt av Una Hakvåg [seniorforsker, Forsvarets forskningsinstitutt (FFI), una.hakvag@ffi.no]

De siste årene har Russland gjennomført en rekke store militærøvelser i Barentshavet, Norskehavet, Nordsjøen, Østersjøen og det nordlige Atlanterhavet. Aktiviteten er av et omfang vi ikke har sett siden den kalde krigen. Sammen med russisk demonstrert vilje til å bruke militærmakt for politisk vinning andre steder i verden har den skapt politisk bekymring i Vesten og blåst nytt liv i forsvarsdebattene i Russlands nordlige naboland.

Den sikkerhetspolitiske utviklingen har ført til en økt akademisk interesse for Russlands utvikling på det militære området. I den stadig voksende mengden av analyser av russisk militærmakt skiller publikasjonene fra svenske FOI, Totalförsvarets forskningsinstitut, seg ut. FOI har i flere år hatt et av de største og mest stabile forskningsmiljøene på russisk forsvars- og sikkerhetspolitikk i Europa. De har utmerket seg ved å være tidlig ute med grundige analyser av nye utviklingstrekk og fenomen, ved sin evne til å se dagens russiske militærmakt og de sikkerhetspolitiske utfordringene den utgjør i et større perspektiv, og ikke minst ved dyptgående kompetanse på heller smale tema som russiske militære øvelser og russisk forsvarsindustri.

Russian Military Capability in a Ten-Year Perspective - 2019 er russlandsmiljøet ved FOIs samlede vurdering av Russlands militære evne (förmåga), og av hvordan den kan tenkes å utvikle seg frem mot 2029. Rapporten, som er skrevet på oppdrag fra det svenske forsvarsministeriet, bygger på et rikt tilfang av ugraderte kilder, og alle kapitlene er fagfellevurdert av internasjonalt anerkjente eksperter på temaet. Rapporten er den niende i rekken, hvorav den første utkom allerede i 1999. Selv om rapporten følger det overordnede oppsettet som er etablert i tidligere publikasjoner, har forfatterne imidlertid ikke latt seg friste til å ta noen snarveier. Innholdet i 2019-utgaven fremstår fullstendig revidert og oppdatert. 
Sammenlignet med andre nyere nordiske studier av russisk forsvarsmakt, som Russia of Power (2019) og Kreml i krig (2018), har Russian Military Capability en vesentlig smalere tematikk. I motsetning til de over nevnte publikasjonene forsøker Russian Military Capability ikke å si noe om det sikkerhetspolitiske forholdet mellom Russland og Vesten, eller om hvordan Russland vil kunne tenkes å agere i en konfliktsituasjon, kun om hvilke regulære militære kapabiliteter som potensielt kan være tilgjengelig.

Rapporten består av i alt fem selvstendige analysekapitler samt introduksjon og konklusjon. De to første analysekapitlene består av en gjennomgang av det russiske forsvarets nåværende strukturelementer etterfulgt av en diskusjon av styrkenes operative evne. Forfatterne har gjort en imponerende jobb med å kartlegge både hvilke strukturelementer som finnes, og hvilke som var faktisk tilgjengelige og kunne benyttes til bestemte oppdrag i ulike krigsteatre. Skal jeg være pirkete, kunne jeg imidlertid ønske meg en tydeligere redegjørelse for hvordan de ulike kategoriene er definert. Særlig gjelder dette vurderingen av tilgjengelighet, hvor det ikke alltid fremgår hvorvidt det er snakk om midlertidig utilgjengelighet som følge av for eksempel rutinevedlikehold av materiellet eller mer langvarig utilgjengelighet som følge av for eksempel mangel på kompetent og tilgjengelig mannskap.

I de tre neste kapitlene drøfter forfatterne de politiske, økonomiske og industrielle rammebetingelsene for den videre forsvarsutviklingen. Bildet som tegnes er av en russisk forsvarsmakt som er kraftig styrket, men som også fremdeles har - og trolig vil ha - en rekke svake punkter. Mesteparten av faktagrunnlaget og argumentene som presenteres er blitt lagt frem av forskerne i andre publikasjoner tidligere og er således velkjent for fagfeller. Lesere som ikke har inngående kjennskap til temaene fra før, vil imidlertid kunne glede seg til svært konsise og gjennomarbeidede analyser basert på mange års forskning. Felles for analysene i denne delen av rapporten er at forfatterne tar utgangspunkt i de siste årenes trender, men samtidig understreker at endring kan komme fort. Nettopp den store usikkerheten knyttet til Russlands videre forsvarssatsing trekkes også frem som et av de sikreste trekkene ved den fremtidige utviklingen i rapportens siste, konkluderende kapittel.

Redaktørene Fredrik Westerlund og Susanne Oxenstierna har gjort en imponerende jobb med rapportens struktur. Til tross for ti ulike forfattere fremstår rapporten som et helhetlig produkt med en tydelig rød tråd og en ensartet stemme. Samtidig gjør detaljnivået $\mathrm{i}$ analysen rapporten til et utmerket utgangspunkt for en åpen, offentlig diskusjon av vurderinger som ellers vanligvis er forbeholdt nasjonale sikkerhetsmyndigheter. Sett bort fra en tidvis overbegeistring for forkortelser i kapittel 3 fremstår teksten språkmessig gjennomarbeidet og lett tilgjengelig. Det er også et stort pluss at rapportens syv kapitler fint kan leses hver for seg. En detaljert innholdsfortegnelse og pedagogiske tabeller gjør dessuten at rapporten fungerer utmerket som oppslagsverk.

Min ene store innvending mot denne publikasjonen er valget av format. Det er vanskelig å komme bort fra at tradisjonelle forskningsrapporter med sitt trauste 


\section{BOKOMTALE | 99}

A4-format, kolonner tettpakket med skrift og Excel-tabeller er de færrestes førstevalg av lesestoff, verken som faglig fordypning eller sengelektyre. Russian Military Capability har imidlertid en kvalitet og en aktualitet som giør at den hadde fortjent en stor leserskare, også utenfor oppdragsgiverne i det svenske forsvarsministeriet. Jeg håper derfor at FOI ved neste revidering vil gjøre noen visuelle grep slik at rapporten kan få den sentrale plassen den fortjener i den nordiske forsvarsdebatten. 